\title{
Effect of Simulated Harvesting on the Plant Composition in the Floating Grasslands of Keibul Lamjao National Park, Manipur
}

\author{
${ }^{1}$ Thounaojam Sanggai Leima* \\ Wildlife Institute of India \\ Chandrabani, Dehradun 248001, Uttarakhand, India \\ ${ }^{3}$ Ruchi Badola \\ Wildlife Institute of India \\ Chandrabani, Dehradun 248001, Uttarakhand, India
}

\author{
${ }^{2}$ Pebam Rocky \\ North Eastern Space Applications Centre \\ Shillong 793 103, Meghalaya, India \\ ${ }^{4}$ Syed Ainul Hussain \\ Wildlife Institute of India \\ Chandrabani, Dehradun 248001, Uttarakhand, India
}

\begin{abstract}
The Keibul Lamjao National Park in Manipur has been a source of livelihood for the peripheral villagers, who have been extracting different types of plant resources throughout the year. A simulation harvesting experiment was carried out in permanent plots in the park to understand the trend in which grass composition might have changed over the years due to human disturbances. Three harvesting regimes of no harvest $(0 \%)$ half harvests $(50 \%)$ and complete harvests $(\mathbf{1 0 0 \%})$ were employed. The result indicated that no harvest of Hedychium coronarium and full harvest for Leersia hexandra yielded positive results. Moderate harvest gave positive results for Phragmites karka, while full harvest significantly decreases the plant density.
\end{abstract}

Keywords- NWFP, Plant harvest, composition, Keibul Lamjao National Park, simulated harvesting

\section{INTRODUCTION}

Studies on interactions between human, plants, animals and the space that they live in is essential for understanding the bio-physical phenomenon associated with integrated ecosystem approach and its management [1]. the physical, chemical and biological processes of environment affect the human species [1],[2] while the biological and social characteristics of the humans (though shaped by evolution) affect their immediate environment. Many protected areas have human settlements within or adjoining them which depend on forest products as a source of sustenance or consumption [3],[4].

The importance of non-timber forest products (NTFPs) were usually considered of little importance and primarily seen of as only local interest [5]. However, during the last few decades, the role of NTFPs on rural development and conservation of natural resources had gained importance. With the ever-increasing population, the harvesting of forest products is no longer sustainable in many areas. Overharvesting of forest products in a non-sustainable manner has had a drastic effect on the forest ecosystems in India [6],[7]. From among different ecosystems, grassland ecosystems were distinguished owing to their species richness which can be attributed to the diversity in site conditions in which they occurred [8] and the maintenance of these ecosystems depended both on natural factors as well as anthropogenic activities [9],[10].
Any process which altered the natural process resulted in reduced stability of communities and posed a threat to the maintenance of floristic diversity of grassland ecosystems [11],[12]. There was also an increasing concern about the response of species and ecosystem to human altered disturbance regimes [13] and undesired plant succession in natural grassland ecosystem. Thus, maintaining a suitable disturbance regime was essential to persist and sustain the biodiversity of grassland ecosystems

There are several natural factors that determine the structure of population and regeneration of given species but anthropogenic disturbances like fire or harvesting some particular species will also alter the plant composition [14]. Keibul Lamjao National Park (KLNP) covering about 40 sq. $\mathrm{km}$. $\left(24^{\circ} 30^{\prime} 00^{\prime \prime} \mathrm{N}, 93^{\circ} 46^{\prime} 00^{\prime \prime} \mathrm{E}\right)$ is the only floating national park located in Bishnupur district of Manipur. Before the park came into existence people living around the park had been deriving benefits from the area. Even after the notification of the national park local villagers around the park have been extracting resources since there are no other option to rely for their livelihoods. It may be difficult to assess to what extent changes were brought about to the plant population due to harvest of the plants in a short study period. To get a quantitative valuation of the effect of harvest on the plant population (composition) of some few selected plants, commonly extracted by the peripheral villagers for livelihoods, an experiment was set up to examine the outcome of simulated harvesting of the target species at different harvesting regimes.

\section{METHODS}

To understand the trend in which grass composition might have changed over the years in the park due to human disturbances permanent plot experiments were conducted for selected four commonly extracted plants namely Zizania latifolia (fodder and thatch material) Phragmites karka (fuel wood) Hedychium coronarium (vegetable) and Leersia hexandra (fish feed/fodder) for the study. Experimental plots were laid in selected areas inside the park where contiguous distribution of the target plants was located. In each of the four sites for the four species, main plots $(10 \mathrm{~m} \times 10 \mathrm{~m})$ were fenced with bamboo poles and a $2 \mathrm{~m}$ buffer was cleared by cutting down grasses along the boundary to prevent damage due to fires from neighbouring areas. Sub plots of $1 \mathrm{~m} \times 1 \mathrm{~m}$ 
were demarcated by fixing jute ropes tied to bamboo poles. Each quadrate was again separated by a buffer of $1 \mathrm{~m}$ in between two quadrates. Three harvesting regimes of no harvest $(0 \%)$ half harvests $(50 \%)$ and complete harvests $(100 \%)$ were employed. The three treatments were randomized within the 3 blocks ( 3 replicates). Initial readings were taken during May 2010 for each quadrate and treatments were given to each plot by simulating the above harvesting methods to each species accordingly to the intensity of harvests. Phragmites karka, Leersia hexandra and Zizania latifolia were cut at the base of the stem/tillers as done during harvesting by the villagers while for Hedychium coronarium part of the rhizomes were also harvested to simulate the way it was being extracted by the villagers. For $0 \%$ harvesting plots no cuts were made, in $50 \%$ plots half of the total stems/tillers were cut selectively while for $100 \%$ harvest plots all the grasses were cut after recording the numbers to study the regenerative potential. Subsequently readings were taken in November, 2010 and the treatments were repeated, and then readings were taken again in April, 2011.

\section{RESULTS}

The results from the simulated harvest experiment of few important grass species showed varied responses to the different treatments. Significant increase in the plant densities were observed for control and complete harvest treatment in Leersia hexandra as compared to 50\% harvesting (TABLE 1 and Fig. 1)

TABLE 1: DENSITY OF INDIVIDUALS BEFORE AND AFTER SUBSEQUENT HARVESTS FOR Leersia hexandra AT DIFFERENT HARVEST INTENSITIES

\begin{tabular}{cccc}
\hline $\begin{array}{c}\text { Level of } \\
\text { harvest }(\boldsymbol{\%})\end{array}$ & $\begin{array}{c}\text { Density May } \\
\mathbf{2 0 1 0}\end{array}$ & $\begin{array}{c}\text { Density Nov } \\
\mathbf{2 0 1 0}\end{array}$ & t-value \\
\hline $\mathbf{0}$ & $245.00 \pm 13.23$ & $250.67 \pm 9.24$ & 2.2 \\
$\mathbf{5 0}$ & $276.67 \pm 25.17$ & $323.33 \pm 40.42$ & 3.2 \\
$\mathbf{1 0 0}$ & $315.00 \pm 5.00$ & $360.00 \pm 17.32$ & 3.6 \\
\hline & Density Nov & Density April & t-value \\
\hline $\mathbf{2 0 1 0}$ & $\mathbf{2 0 1 1}$ & $5.0^{*}$ \\
$\mathbf{5 0}$ & $250.67 \pm 9.24$ & $254.00 \pm 10.39$ & 2.2 \\
$\mathbf{1 0 0}$ & $323.33 \pm 40.42$ & $341.67 \pm 34.49$ & $4.9^{*}$ \\
\hline
\end{tabular}

(* = significant at 0.10 level)

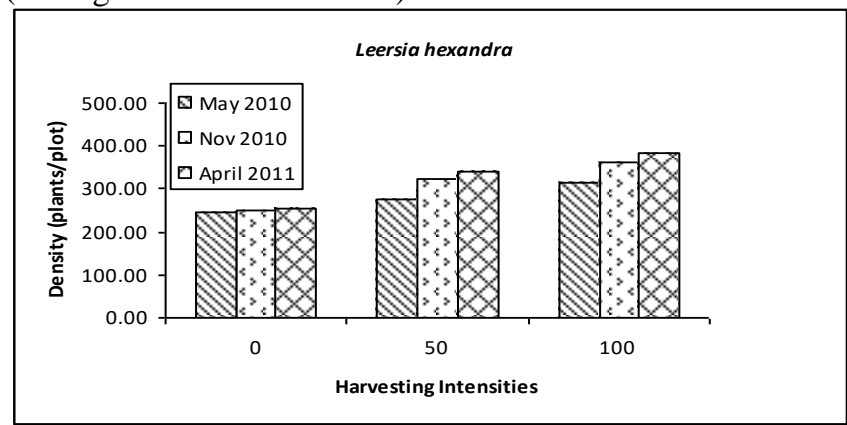

Fig. 1: Densities of plant before and after subsequent harvests of Leersia hexandra at different harvesting intensities

In the case of Hedychium coronarium, controlled plot showed a significant increase in the plant densities (TABLE 2) whereas there was a significantly drastic decrease in densities in the $50 \%$ harvest. Decrease in plant densities was also observed in complete harvest plots though it was not significant (Fig. 2).

TABLE 2: DENSITY OF INDIVIDUALS BEFORE AND AFTER SUBSEQUENT HARVESTS FOR Hedychium coronarium AT DIFFERENT HARVEST INTENSITIES.

\begin{tabular}{cccc}
\hline $\begin{array}{c}\text { Level of } \\
\text { harvest }(\boldsymbol{\%})\end{array}$ & $\begin{array}{c}\text { Density May } \\
\mathbf{2 0 1 0}\end{array}$ & $\begin{array}{c}\text { Density Nov } \\
\mathbf{2 0 1 0}\end{array}$ & t-value \\
\hline $\mathbf{0}$ & $7.67 \pm 2.1$ & $11.3 \pm 2.31$ & $11.0 *$ \\
$\mathbf{5 0}$ & $12.00 \pm 5.20$ & $8.67 \pm 1.86$ & 2.8 \\
$\mathbf{1 0 0}$ & $8.00 \pm 6.56$ & $4.00 \pm 2.00$ & 1.5 \\
\hline & Density Nov & Density April & t-value \\
\hline $\mathbf{2 0 1 0}$ & $\mathbf{2 0 1 1}$ & 2.6 \\
$\mathbf{5 0}$ & $11.3 \pm 2.31$ & $14.33 \pm 1.16$ & $8.0 *$ \\
$\mathbf{1 0 0}$ & $8.67 \pm 1.86$ & $6.00 \pm 2.65$ & 4.0 \\
\hline
\end{tabular}

(* = significant at 0.10 level $)$

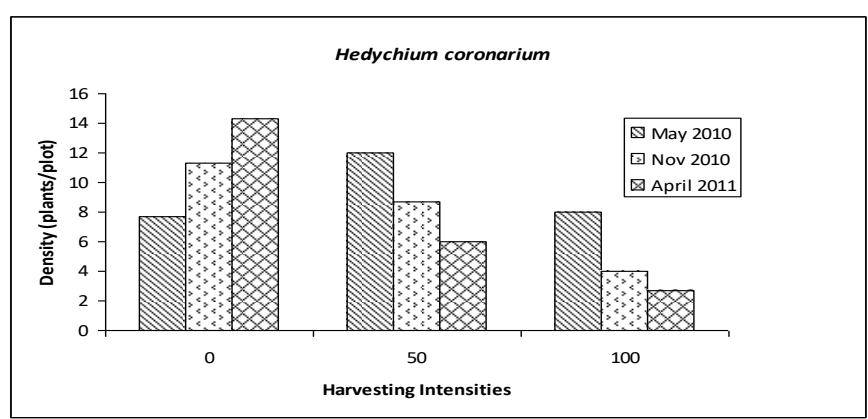

Fig. 2: Densities of plant before and after subsequent harvests of Hedychium coronarium at different harvesting intensities.

In the case of Zizania latifolia, $50 \%$ and $100 \%$ harvesting intensities did not have significant impact on the densities of plants in the plots (TABLE 3) but significant increase in the density was observed in $0 \%$ harvest (Fig. 3). Complete harvesting in Phragmites karka significantly reduced the plant densities in the plots while no harvest showed a significant increase in density (TABLE 4) whereas $50 \%$ harvesting shows a slight increase in densities which was not significant as compared to the control (Fig. 4).

Table 3: DENSITY OF INDIVIDUALS BEFORE AND AFTER SUBSEQUENT HARVESTS FOR Zizania latifolia AT DIFFERENT HARVEST INTENSITIES

\begin{tabular}{cccc}
\hline $\begin{array}{c}\text { Level of } \\
\text { harvest }(\boldsymbol{\%})\end{array}$ & $\begin{array}{c}\text { Density May } \\
\mathbf{2 0 1 0}\end{array}$ & $\begin{array}{c}\text { Density Nov } \\
\mathbf{2 0 1 0}\end{array}$ & t-value \\
\hline $\mathbf{0}$ & $55.00 \pm 21.79$ & $63.00 \pm 22.61$ & $13.9 *$ \\
$\mathbf{5 0}$ & $45.00 \pm 15.00$ & $56.67 \pm 16.07$ & 3.5 \\
$\mathbf{1 0 0}$ & $50.33 \pm 20.01$ & $56.00 \pm 17.69$ & 2.4 \\
\hline & Density Nov & Density April & t-value \\
& $\mathbf{2 0 1 0}$ & $\mathbf{2 0 1 1}$ & $7.0^{*}$ \\
$\mathbf{0}$ & $63.00 \pm 22.61$ & $67.67 \pm 23.11$ & 2.8 \\
$\mathbf{5 0}$ & $56.67 \pm 16.07$ & $64.00 \pm 18.25$ & 3.8 \\
\hline
\end{tabular}

(* = significant at 0.10 level) 


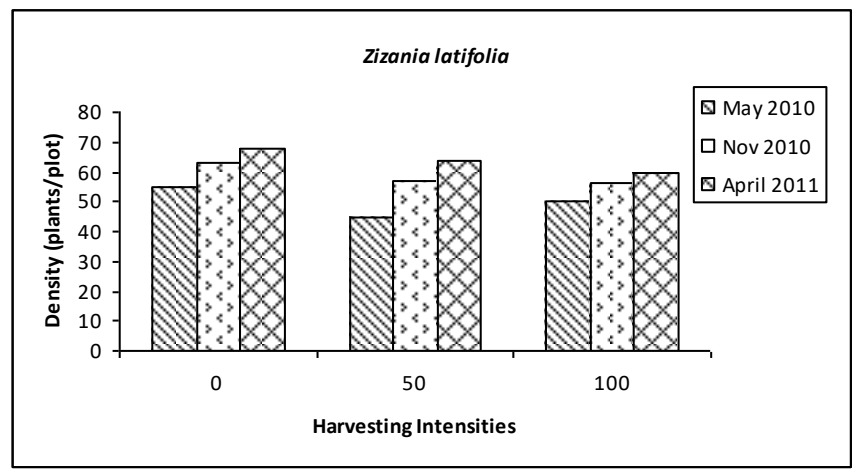

Fig. 3: Densities of plant before (May 2010) and after subsequent harvests Zizania latifolia at different harvesting intensities.

TABLE 4: DENSITY OF INDIVIDUALS BEFORE AND AFTER SUBSEQUENT HARVESTS FOR Phragmites karka AT DIFFERENT HARVEST INTENSITIES

\begin{tabular}{cccc}
\hline $\begin{array}{c}\text { Level of } \\
\text { harvest } \\
(\boldsymbol{\%})\end{array}$ & $\begin{array}{c}\text { Density } \\
\text { May 2010 }\end{array}$ & $\begin{array}{c}\text { Density Nov } \\
\mathbf{2 0 1 0}\end{array}$ & t-value \\
\hline $\mathbf{0}$ & $20.67 \pm 11.02$ & $25.67 \pm 13.05$ & 3.3 \\
$\mathbf{5 0}$ & $49.67 \pm 25.70$ & $61.67 \pm 33.29$ & 1.8 \\
$\mathbf{1 0 0}$ & $42.67 \pm 8.74$ & $13.33 \pm 5.77$ & $5.5^{*}$ \\
\hline & Density Nov & Density & t-value \\
\hline $\mathbf{2 0 1 0}$ & April 2011 & $4.4^{*}$ \\
$\mathbf{5 0}$ & $25.67 \pm 13.05$ & $31.00 \pm 14.73$ & 3.7 \\
$\mathbf{1 0 0}$ & $61.67 \pm 33.29$ & $67.00 \pm 35.68$ & 3.8 \\
\hline
\end{tabular}

(*= significant at 0.10 level)

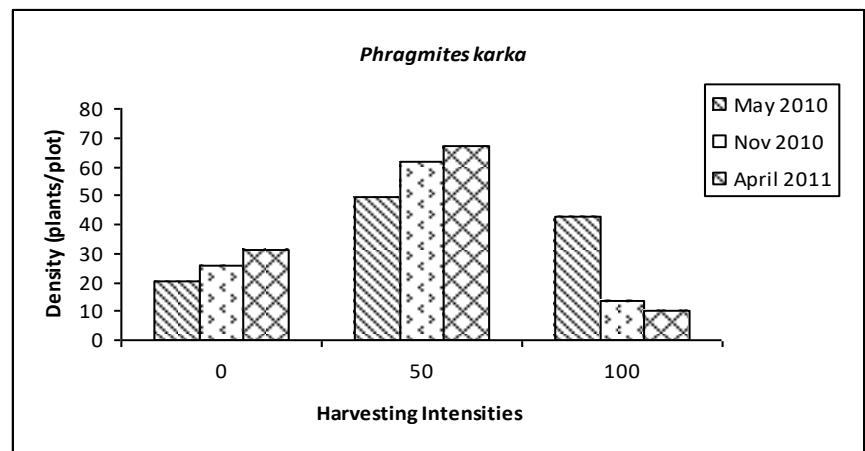

Fig. 4: Densities of plant before (May 2010) and after subsequent harvests of Phragmites karka at different harvesting intensities

\section{Discussions}

The harvesting simulation results indicated that increased harvesting intensities decreased the plant density in case of Hedychium coronarium and complete harvest was detrimental to the regrowth of Phragmites karka. This indicated that the results from the quadrate study and comparison over the years confirmed to one of the probable reason for the decreased occurrence of Phragmites karka. The cause of the change may be due to the continuous harvesting of Phragmites karka resulting in increased abundance of species with vegetative reproduction due to flowering being hindered [15]. Excessively intensive management as well as complete abandonment or improper utilization of grassland results in deterioration of both its natural and economic value. Most often it resulted in disappearance of valuable species and appearance of unwelcome expansive taxon [16],[17].

Role of other anthropogenic activities might also have resulted in the change in composition of the KLNP grassland. Fire could be another factor which might have contributed to the change. Fire was not only significant in maintaining an open sward, but also had the potential to control the invasion and spread of exotic species in native grasslands [18],[19]. However, on the contrary in the present study, unwanted plants like Pteris sp. came up in areas that were burned though this needs to be substantiated with further studies. Frequent burning in Phragmites karka dominated grasslands of Kaziranga National Park lead to replacements by Saccharum, Themeda and Imperata species [20]. Few studies had verified the claims that fire was beneficial but burning season remained the least understood component of the disturbed regime [21]. Burning may have exerted selective forces altering the composition of the native community over the years in Kalsow Prairie, Iowa [22]. Another probable reason for the change in the composition may be the nutrient loading in the lake ecosystem from inflowing river from the main settlement areas in the valley. It was also reported that in a year 372.6 ton of nitrate nitrogen was received from the inflowing rivers out of which 76.8 ton was deposited in the Loktak Lake water [23] and nitrogen concentration of the lake water was estimated at $2.3 \mathrm{~g} \mathrm{~m}^{-3}$. This high loading of nutrient in the lake water had also led to proliferation of floating meadows in open waters of the lake. This might also be one of the causes for the change in the overall grassland composition as nitrogen addition experiments in grasslands indicated that one of the consequences was a reduction in plant diversity [24] dominance of a few species and suppression of many other species [25].

\section{CONCLUSIONS}

The people surrounding the KLNP have been harvesting the plant resources for different uses from the floating grassland. Over the years the villagers might have also overharvested for more economic gains. From the present experimental trial based on simulation of the harvesting pattern, it has been found that extraction of the plant resources bears a negative effect to the regeneration and subsequently may alter the composition of the grass species. While grass species like Leersia hexandra and Zizania laifolia have a positive effect after disturbance or complete harvest others have some negative effect, but in lesser degree when the harvests are just moderate. For better management of the park resources controlled/regulated harvesting and moderate cutting/ harvesting of the plant resources are recommended for maintaining a balanced plant composition to sustain the wild population of Sangai in the park.

\section{ACKNOWLEDGMENT}

The authors would like to thank Director, Wildlife Institute of India, Dehradun, for the support and encouragements and all the park officials of KLNP who helped during the field experiments. 


\section{REFERENCES}

[1] C. Folke, C. Fabricius, G. Cundill, L. Schultz, C Queiroz, Y. Gokhale, A. Marı'n, E. Camac-Ramirez, S. Chandola, M.T. Ahmed, B.Talukdar, A. Argumedo and F.C. Torres, "Communities, Ecosystem and Livelihoods". In D. Capistrano, C. Samper, M. Lee and C. RaudseppHearne (eds.): Ecosystems and human well-being: Multiscale assessments. Washington, DC: Island Press, 2005, 261-277pp

[2] J.M. Grove and W.R. Burch, "A social ecology approach and applications of urban ecosystem and landscape analyses: a case study of Baltimore, Maryland”. Urban Ecosystems, 1(4): 259-275, 1997.

[3] C.S. Silori and B.K. Mishra, "Assessment of livestock grazing pressure in and around the elephant corridors in Mudumalai Wildlife Sanctuary, South India" Biodiversity and Conservation, 10: 2181-2195, 2001.

[4] P. Davidar, M. Arjunan, and J.P. Puyravaud, "Why do local households harvest forest products? A case study from the southern Western Ghats, India”, Biological Conservation, 141: 1876-1884, 2008

[5] J.E.M. Arnold and M.R. Pérez, "Can non-timber forest products match tropical forest conservation and development objectives?" Ecological Economics, 39: 437-447, 2001.

[6] V. Anitha, P.K. Muraleetharan and A.S. Binilkumar, "Natural resource depletion in protected areas: Socio economic linkages", Indian Journal of Social Development, 3: 44-59, 2003.

[7] S.N. Rai and S.K. Chakrabarti, "Demand and supply of fuelwood and timber in India", Indian Forester, 3: 263-279, 2001.

[8] C. Traba, P. Wolanski and K. Oklejewicz, "Floristics diversity of selected nonforest plant communities in the San river valley", Ann. UMCS, Sectio E, 61: 267-275 (in Polish with English summary) 2006.

[9] J. Isselstein, B. Jeangros and V. Pavlu, "Agronomic aspects of biodiversity targeted management of temperate grasslands in Europe: A review", Agronomy Research, 3(2): 139-151, 2005.

[10] T. Zaluski, "Changes of vegetation in the "Bielinek" nature reserve. Ecological Questions, 2/2002: 175-180, 2002.

[11] J. Šantrůček, M. Svobodová and V. Brant, "Changes of botanical composition of grass stands under different types of management". Rostl. Výr, 48: 499-504, 2002.

[12] M. Štýbnarová, J. Hakl, J. Krhovjáková and J. Pozdišek, "Botanica composition of pasture sward influence by intensity of utilization and mineral fertilization", Grassland Science in Europe, 14: 261-264, 2009.

[13] T. C. Foin, S.P.D. Riley, A.L. Pawley, D.R. Ayres, T.M. Carlsen, P.J. Hodum and P.V. Switzer, "Improving recovery planning for threatened and endangered species". BioScience, 48: 177-184, 1998
[14] P. Hall and K.S. Bawa, "Methods to assess the impact of extraction of non-timber forest products on plant populations", Economic Botany, 47: 215-219, 1993.

[15] M. Fischer and S. Wipf, "Effect of low-intensity grazing on the species-rich vegetation of traditionally mown sub-alpine meadows", Biological Conservation, 104: 1-11, 2002.

[16] H. Laser, "Long-term and short-term effects of undisturbed plant succession, mulching, and meadow utilisation on the botanical diversity in a moist Arrhenatherion elatioris", Grassland Science Europe, 7: 806-807, 2002.

[17] L. Nadolna, "The effect of restored grassland mowing on the productivity and environmental quality of fallowed grasslands in the Sudetes". Woda - Środowisko - Obszary Wiejskie, 27: 89-105, 2009.

[18] J. Stuwe and R.F. Parsons, "Themeda australis grasslands on the Basalt Plains Victoria: floristics and management effects", Australian Journal of Ecology, 2: 467-476, 1977.

[19] J. Stuwe, "An Assessment of the Conservation Status of Native Grasslands on the Western Plains, Victoria and Sites of Botanical Significance". Technical Report Series No. 48, Department of Conservation, Forests and Lands, Melbourne, 1986.

[20] P.K. Khatri and K.N. Barua, Structural composition and productivity assessment of the grassland community of Kaziranga National Park, Assam. Indian Forester, 137(3): 290-295, 2011.

[21] A.M. Gill, R.A. Bradstock and J.E. Williams, "Fire regimes and biodiversity: legacy and vision”, In R.A. Bradstock, J.E. Williams and A. M. Gill. (eds.): Flammable Australia. The Fire Regimes and Biodiversity of a Continent. Cambridge University Press. UK, 2002, 429-447pp.

[22] M.E. Dornbush, "Plant community change following fifty-years of management at Kalsow Prairie Preserve, Iowa, U.S.A", American Midland Naturalist, 151: 241-250, 2004.

[23] L. Kosygin, "Limnological studies of Loktak Lake with specia reference to role of phumdis in the lake", In Trisal, C.L. and Manihar, Th. (eds.): Management of Phumdis in Loktak Lake, New Delhi, 2002, 18-21pp

[24] M.R. Aguiar, "Biodiversity in grasslands: Current Changes and future scenarios", In S.G. Reynolds, S.G. and Frame, J. (eds.) Grasslands: Developments Opportunities Perspectives, FAO and Science Publishers Inc. 2005, 261-280pp

[25] J. Silvertown, "The dynamics of a grassland ecosystem: botanical equilibrium in the Park Grass Experiment", Journal of Applied Ecology, 17: 491-504, 1980 